\title{
Preface: EU social politics coming out from the cold
}

\section{Anton Hemerijck}

It is extremely difficult for social scientists to do empirical and theoretical justice to the politics of European integration when it comes to social and employment policies. The European Union (EU) conjures up a hybrid polity where economic and social objectives are often in tension with each other due, on the one hand, to the changing political conditions in the Member States, but also because of the unrelenting dynamic EU policy development. As social policy expansion preceded European market integration, for historical reasons, the EU is a political union of national welfare states. With the passing of time, EU single market and currency integration fundamentally intruded on the policy autonomy of national welfare provision. In the process, EU social regulation matured, albeit in fits and spurts. Strikingly, in the wake of the Great Recession, EU social integration came to a grinding halt. From 2012 on, progressive macroeconomic stabilisation, on the wing of the establishment of the European Stability Mechanism and the early steps towards a Banking Union, culminating in Mario Draghi's vow to do 'whatever it takes' to secure the survival of the euro, have brought Social Europe back with a vengeance. Most recently, in response to the Covid-19 pandemic that shook the world in 2020, heterodox monetary policy was joined by an element (temporary) of EU fiscal solidarity, to incentivise members to bolster work, care and welfare provision in a productive rather than regressive fashion.

On the basis of evidential breakthroughs, we should however be careful not to naively anticipate institutional leaps forward of the EU taking over core welfare functions from the Member States. Equally misguided is the still dominant assertion in the literature that single market and monetary integration are anathema to the normative and functional integrity of Europe's popular national welfare states. At best, EU political integration may come to better protect and advance the integrity of national social policy, to create a 'holding environment for flourishing European welfare states'. But this conjures up a political enterprise par excellence, prone to contestation, push-back and -forward. And here lies the central gist of Francesco Corti's timely book 
publication, bringing to the foreground the political contingencies of EU-level social politics over the epoch of the Great Recession.

The book covers important new ground in understanding the supranational politicisation of Social Europe. While most country-comparative welfare state research has shifted to the electoral turn demand side of political contention and party competition, Francesco Corti puts political conflict and alignment across EU institutions, from the Commission, the European Parliament and the European Council, centre-stage. Throughout a series of well-crafted case studies, covering the adoption of the European Pillar of Social Rights; the revision of the Posting of Workers Directive; the Social Investment Package agenda-setting; the (unresolved) debate over the European Unemployment Benefit (Re)insurance; and the 'socialisation' of the European Semester, Francesco Corti delivers a pioneering empirical analysis of the political comeback of Social Europe over the past decade.

Throughout the case studies, the book exposes how deeply interconnected market, currency and Social Europe has become in the wake of the Euro crisis. The austerity-reflex of the Six Pact, the Fiscal Compact and the Two Pack, all embedded in the European Semester, faltered in terms of political legitimacy. As the austerity reflex reinforced high (youth) unemployment and rising inequality, ex-negativo, it set a new stage for Social Europe, but not per se a victorious one. Social Affair Commissioner Andor's success in setting a comprehensive social investment agenda had no immediate impact on the austerity bias in the policy platform of the Barroso Commissions. Yet, it prepared the ground for new diagnoses and novel policy solutions to be taken seriously. The new compromise between EU market integration, social regulation and national welfare provision, more assertively bolstered by the Juncker administration through the Pillar of Social Rights, eventually received fiscal backing after the coronavirus outbreak. In other words, the progressive Covid-19 policy response finds it roots, according to Francesco Corti, in the hard economic and political lessons learned from the misguided austerity reflex experience. His book obviously corrects the prevailing view in the academic literature that Social Europe remains an empty shell, but Corti's disciplined empirical research also departs from more naive scholars who too easily assert that EU 'soft policy' agenda-setting catalyses 'hard' regulation in its wake without cumbersome political conflict and institutional competition. The book is a must-read for academics and policy makers alike. 